\title{
Grey squirrels in central Italy: a new threat for endemic red squirrel subspecies
}

\author{
Anna Lisa Signorile • Daniele Paoloni • \\ Daniel C. Reuman
}

Received: 26 June 2013/ Accepted: 5 March 2014/Published online: 25 March 2014

(C) The Author(s) 2014. This article is published with open access at Springerlink.com

\begin{abstract}
A new population of the invasive American Eastern grey squirrel (Sciurus carolinensis) has recently settled in central Italy from an accidental release in Perugia, Umbria in the early 2000s. The grey squirrel is known to compete with and exclude native red squirrels ( $S$. vulgaris) in the British Isles and Northern Italy, so it represents a potentially important new conservation threat to the red squirrel subspecies of south and central Italy, S. vulgaris italicus and $S$. v. meridionalis, which are endemic to peninsular Italy. The grey squirrel population range in Perugia is currently expanding at a rate of about $0.29 \mathrm{~km} / \mathrm{year}$ (SD 0.19), slower than grey squirrel invasions elsewhere in Europe. Nuclear DNA analysed at 12
\end{abstract}

\footnotetext{
A. L. Signorile $(\bowtie) \cdot$ D. C. Reuman $(\bowtie)$

Imperial College London, Silwood Park Campus, Buckhurst Road, Ascot, Berkshire SL5 7PY, UK

e-mail: lisa.signorile@gmail.com

D. C. Reuman

e-mail: d.reuman@imperial.ac.uk
}

\author{
A. L. Signorile \\ Institute of Zoology, Zoological Society London, \\ Regent's Park, London NW1 4RY, UK
}

D. Paoloni

Department of Cellular and Environmental Biology, University of Perugia, Via Elce di Sotto, 06123 Perugia, Italy

D. C. Reuman

Laboratory of Populations, Rockefeller University, 1230 York Ave, New York, NY 10065, USA different microsatellite loci revealed that the grey squirrels in Perugia have extremely low genetic diversity, consistent with a small founder size. Genetic assignment tests indicate that the Perugia population was founded by translocations from an established population in Piedmont, Italy. No genetic substructure is evident yet in the Perugia population. These results together have serious consequences for the management of the grey squirrel invasion in Perugia and the conservation of the red squirrel subspecies: the Perugia grey squirrel population should be eradicated if politically feasible; otherwise new releases of grey squirrels, especially from sources other than the Piedmont population, should be prevented because such introductions could increase genetic diversity, thereby potentially increasing population range expansion rate to the much higher levels seen for more diverse grey squirrel populations elsewhere in Europe.

Keywords Invasive - Alien species ·

Microsatellites · Sciurus carolinensis .

Translocations $\cdot$ Competition

\section{Introduction}

Most invasions do not spread as a simple wave in a diffusion-like process from the initial introduction site. Instead, invaders usually radiate from multiple, separate foci arising either from multiple introductions from their native range or from long-distance jumps of 
dispersal, often human mediated, from the first introduced population (Kot et al. 1996). These foci can differ greatly in size and ability to spread as a consequence of the sizes of their founding events, their dates of establishment, local environments, and stochastic events which are more extreme in small populations (Zeisset and Beebee 2003; Walker et al. 2003; Thulin et al. 2006). The spreading of the American Eastern grey squirrel (Sciurus carolinensis) in Europe is an archetype of this pattern.

The grey squirrel invasion in Europe, and especially in Great Britain, is one of the best documented cases of an animal invasion anywhere, and has caused damage and great conservation concern: the species is considered one of the most invasive species worldwide (Lowe et al. 2000). The grey squirrel is highly adaptable, and this adaptability, together with multiple introductions and translocations in Great Britain in the 19th and 20th centuries (Middleton 1930, 1931), have contributed to the spread of the species in the United Kingdom. The grey squirrel's expansion throughout most of Britain (Lloyd 1983; Reynolds 1985; Tompkins et al. 2003) has allowed researchers to observe and begin to understand the mechanisms and consequences of invasive population spread (Rushton and Garson 1995; Rushton et al. 1997, 2002), including aspects of disease dynamics, competitive displacement of the native red squirrel, Sciurus vulgaris (Gurnell et al. 2004), and invasion population genetics (Signorile. et al. in review; Sainsbury et al. 2008). In Italy, grey squirrels were first introduced in 1948 in Turin, a population that is now spreading steadily and leading to red squirrel local extinctions (Wauters et al. 1997; Wauters and Gurnell 1999; Wauters et al. 2002). Other grey squirrel population foci have also appeared in Genoa (Venturini et al. 2005) and, more recently, in several areas in Lombardy (Martinoli et al. 2010). With the exception of a failed introduction in Rome (Bertolino et al. 2005), no mention of grey squirrels in the peninsular part of Italy has been reported except for the population in Perugia, Umbria, that we study here; that population sprang from an introduction that occurred at the beginning of the 2000s (Paoloni et al. 2010). Squirrels were accidentally released in a suburban wildlife park near Perugia and from there they have spread to the edge of the city and outward away from the city (Paoloni et al. 2012).

An endemic subspecies of Eurasian red squirrel, S. vulgaris italicus Bonaparte, 1838, lives in Central
Italy around Perugia (Toschi 1965; Lurz et al. 2005), and another subspecies, S. v. meridionalis Lucifero, 1907, lives in southern Italy, in Calabria. Although it is known that the range of $S$. v. italicus includes the north-central part of the Apennine Mountains (Toschi 1965; Sidorowicz 1971; Amori et al. 2008), the distribution of this red squirrel subspecies has never been clearly mapped and no data on its abundance are available. Although we here refer to $S$. v. italicus and S. v. meridionalis as subspecies because they have been traditionally identified as such based on phenotypic measurements (Sidorowicz 1971; Lurz et al. 2005), a more recent study using mitochondrial DNA and microsatellites suggests that, of these two, only $S$. v. meridionalis is sufficiently differentiated from other S. vulgaris samples to be properly called a subspecies (Grill et al. 2009).

At the moment, red and grey squirrels both occur together in the Perugia area, but grey squirrels have eventually excluded red squirrels in essentially all previous areas the two species have come into contact. So the presence of grey squirrels in Perugia represents a serious conservation threat for two poorly known red squirrel subspecies-in the longer term, the grey squirrel could cause their extinction. Therefore understanding the spread of the new grey squirrel population and its mechanisms, the origin of the new population, its founding size, genetic structure, and the possible presence of ecological and genetic constraints that could affect grey squirrels' ability to spread in the new area is a priority for the conservation of S. v. italicus and S. v. meridionalis, and is the aim of this paper. We accomplish this aim by evaluating the empirical support for two hypotheses: (1) the population in Perugia grew from a small introduction from Piedmont, Italy, a population known to have low genetic diversity (Signorile et al. in review), and hence Perugia squirrels have very low genetic diversity; and (2) population range expansion in Perugia is very slow compared to other populations in Europe, possibly because of the low genetic diversity. Alternative hypotheses considered for origins of the introduction include the United Kingdom and the United States of America. We evaluate the implications of results for future expansion and management of the grey squirrel and for the nature of the threat the grey squirrel represents to the red squirrel subspecies. 


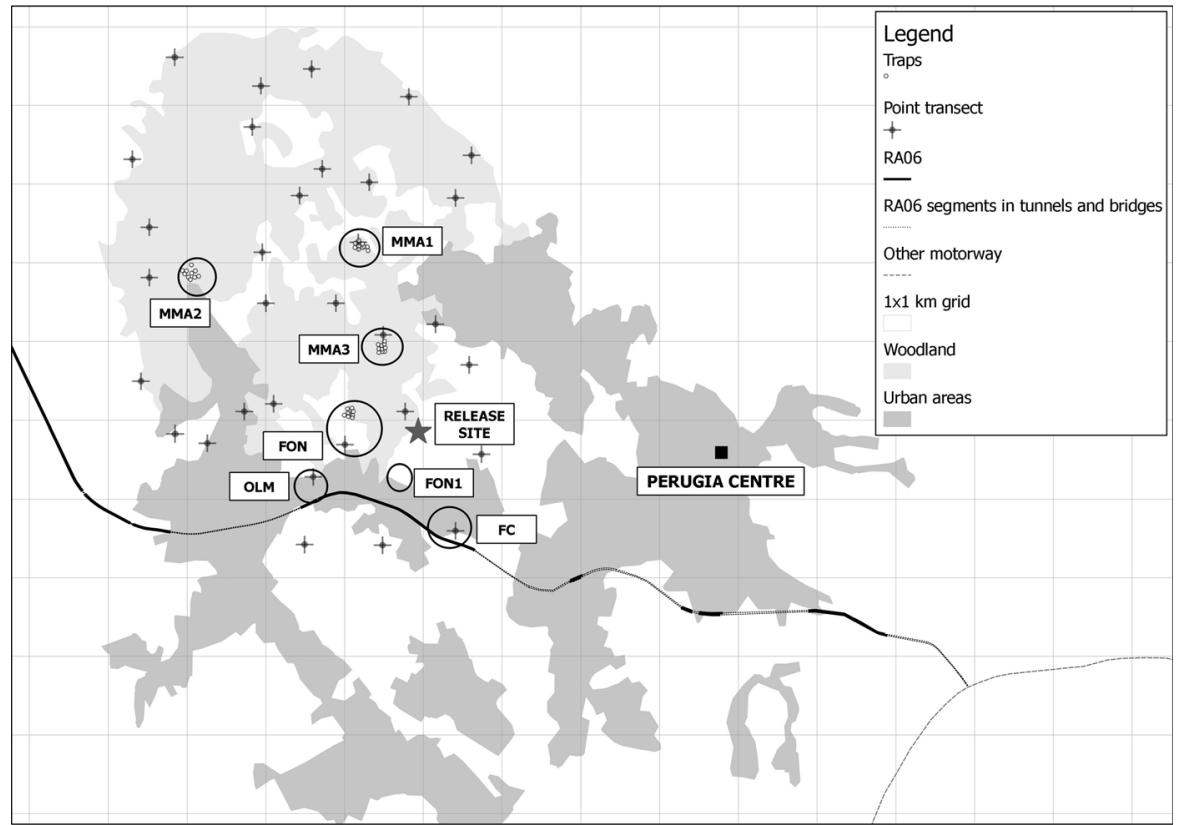

Fig. 1 Map of grey squirrel trapping and survey effort in Monte Malbe, Perugia. Circled areas represent the positions of genotyped squirrels

\section{Methods}

Study areas and sampling

Seven grey squirrels were reported to have been purchased in 1999 from a pet retailer by a private wildlife park near the city of Perugia. The squirrels were kept on display in wire cages outdoors, and these animals were reported to have escaped at the beginning of the 2000s. The wildlife park is located within the Site of Community Importance IT5210021, called "Monte Malbe" (Lat: 43.133 Long: 12.367), west of the city of Perugia, Umbria. It is a 945 ha forested area characterized by a mosaic of different vegetation patterns, dominated by holm oak (Quercus ilex) and other large-seeded deciduous trees such as chestnut (Castanea sativa).

Samples for genetic analysis were collected from road kills and from live-trapping sessions scattered at locations within the Monte Malbe site: Ferro di Cavallo (FC), Fontana (FON), Fontana 1 (FON1), Olmo 1 (OLM), MonteMalbe 1 (MMA1), MonteMalbe 2 (MMA2), and MonteMalbe 3 (MMA3) (Fig. 1). Roadkills were collected throughout 2010-2011. Live trapping was done from November 2011 to June 2012 using 10 ground-placed Tomahawk traps (model 104,
Tomahawk Live Trap Co.). Tissue samples were taken from the ear pinna and placed in an Eppendorf vial containing $95 \%$ ethanol and stored at $4{ }^{\circ} \mathrm{C}$ until DNA extraction. Squirrel densities were estimated at MMA1 and FON1 by the removal method (Zippin 1958).

DNA extraction and genotyping

DNA was collected from 25 animals. From each sample, about $5 \mathrm{mg}$ of tissue were used to extract DNA according to the Wizard SV 96 Genomic DNA Purification System (Promega) protocol. Ten to twenty $\mathrm{nmol} / \mu \mathrm{L}$ of DNA from each sample were amplified with 6 microsatellite markers developed for S. vulgaris, SCV1, SCV4, SCV6, SCV13, SCV18, SCV31 (Hale et al. 2001), and 6 developed for $S$. niger, FO11, FO36, FO46, FO54, FO63 (Fike and Rhodes 2009), DFS27 (Lance et al. 2003), for a total of 12 loci. Multiplex set ups and DNA amplification by PCR were carried out as described in (Signorile et al. in review). Diluted PCR products were run with an ABI Prism 3130 Genetic Analyzer (Applied Biosystems) and alleles were scored with GeneMapper 4.0. To minimise genotyping errors, PCRs were repeated twice and positive and negative controls were added to the plate. 
Data analysis

All genotypes were scored for deviations from HardyWeinberg equilibrium with a Fisher's exact test as implemented in GENEPOP 4.1 (Raymond and Rousset 1995) (default parameters were used). Fstat for Windows (2.9.3.2) (Goudet 1995) was used to test for pairwise linkage disequilibrium. This software runs the analysis using the Markov chain algorithm as implemented by Raymond and Rousset (1995) and automatically gives the adjusted $P$ value for the $5 \%$ nominal level after Bonferroni correction. MICROCHECKER 2.2.3 (van Oosterhout et al. 2004) was used to assess if there was any evidence for allelic drop-outs, null alleles or stuttering. Mean number of alleles and inbreeding coefficient $\left(\mathrm{F}_{\mathrm{IS}}\right)$ values were calculated and tested for significance with Genetix 4.05 (Belkhir et al. 2004).

STRUCTURE 2.3.4 (Pritchard et al. 2000) was used to assess if there was any substructure in the Perugia population. This software assigns individuals to clusters using a Bayesian approach. A burn-in period discarding 100,000 Markov Chain Monte Carlo steps from each run was selected, followed by a chain of length 200,000 that was used. An admixture model with correlated allelic frequencies was chosen, with 20 iterations for each $\mathrm{K}$.

Assignment tests were run with the software Oncor (Kalinowski et al. 2008). This software uses use a partial Bayesian method derived from the exclusion method of Rannala and Mountain (1997). A baseline composed of 338 individuals clustered in 5 populations from North and East England, Northern Ireland, Piedmont, Italy (Signorile et al., in review), and the USA (Table 1) was used for the exclusions. $95 \% \mathrm{CI}$ were estimated with 100,000 bootstrap resamplings. Fstat was also used to calculate the genetic distance $\left(\mathrm{F}_{\mathrm{ST}}\right)$ of Perugia squirrels from the putative populations in the database, as implemented by Weir and Cockerham (1984).

\section{Squirrel spread surveys}

Data on squirrel presence and spread since the time of introduction was collected from 2010 through 2012 with point transects and hair tubes scattered across Monte Malbe. The position of each point transect (Fig. 1) was opportunistically chosen to maximize visibility in this very close and dense canopy, but also
Table 1 Population origins and numbers of individuals in the reference database used to investigate the source of the new grey squirrel population in Perugia

\begin{tabular}{|c|c|c|}
\hline Location & Lat/Long & $\mathrm{N}$ \\
\hline Piedmont & & 125 \\
\hline Stupinigi & $54.80^{\circ} 6.81^{\circ}$ & 19 \\
\hline Piobesi & $54.64^{\circ} 6.82^{\circ}$ & 6 \\
\hline Borgo Cornalese & $54.40^{\circ} 6.60^{\circ}$ & 54 \\
\hline Racconigi & $54.31^{\circ} 6.51^{\circ}$ & 32 \\
\hline Cavallermaggiore & $54.27^{\circ} 6.39^{\circ}$ & 14 \\
\hline Northern Ireland & & 122 \\
\hline Derrynoyd Forest & $44.99^{\circ} 7.60^{\circ}$ & 32 \\
\hline Drum Manor & $44.94^{\circ} 7.59^{\circ}$ & 20 \\
\hline Loughgall Forest & $44.91^{\circ} 7.73^{\circ}$ & 22 \\
\hline Gosford & $44.79^{\circ} 7.65^{\circ}$ & 29 \\
\hline Drumbanagher & $44.72^{\circ} 7.68^{\circ}$ & 19 \\
\hline Northumberland & & 38 \\
\hline Briar Wood & $54.95^{\circ} 2.32^{\circ}$ & 8 \\
\hline River Tyne Corridor & $55.00^{\circ} 2.11^{\circ}$ & 10 \\
\hline Morpeth & $55.17^{\circ} 1.70^{\circ}$ & 20 \\
\hline East Anglia & $52.19^{\circ} 0.83^{\circ}$ & 30 \\
\hline West Virginia & $39.00^{\circ}-80.23^{\circ}$ & 23 \\
\hline
\end{tabular}

selecting spots were the composition of the arboreal vegetation was representative of the whole area. In each sampling location three different observations of $30 \mathrm{~min}$ each were carried out in different seasons during squirrels' peak activity times (early morning and late afternoon in springtime and summer, midday in autumn and winter). Further records were collected from citizens, park-owners, roadkills and occasional sightings and their positions georeferenced. All the point transect observations were carried out by one of the authors (DP) and a trained field worker. All the other observations were verified by DP. Since the study area has high-density tree growth, very poor visibility, and difficult terrain, distance sampling or other visual methods of assessing squirrel density could not be used.

Approximate squirrel spread rate since the release date was estimated, with uncertainties, by a simple method that is very similar to methods of Andow et al. (1990). The method measured maximum linear expansions from the release point in the eight main compass directions (Fig. 2). The eight distances were computed and two possible starting dates were used (2000 and 2003) to take into account uncertainties in 
Fig. 2 Spatial distribution of red and grey squirrels in the urban and sub-urban area of Perugia and distances from the release point along the main directions of the compass. Squirrel records include trappings, sightings, and road kills from all years data were gathered (2010-2012)

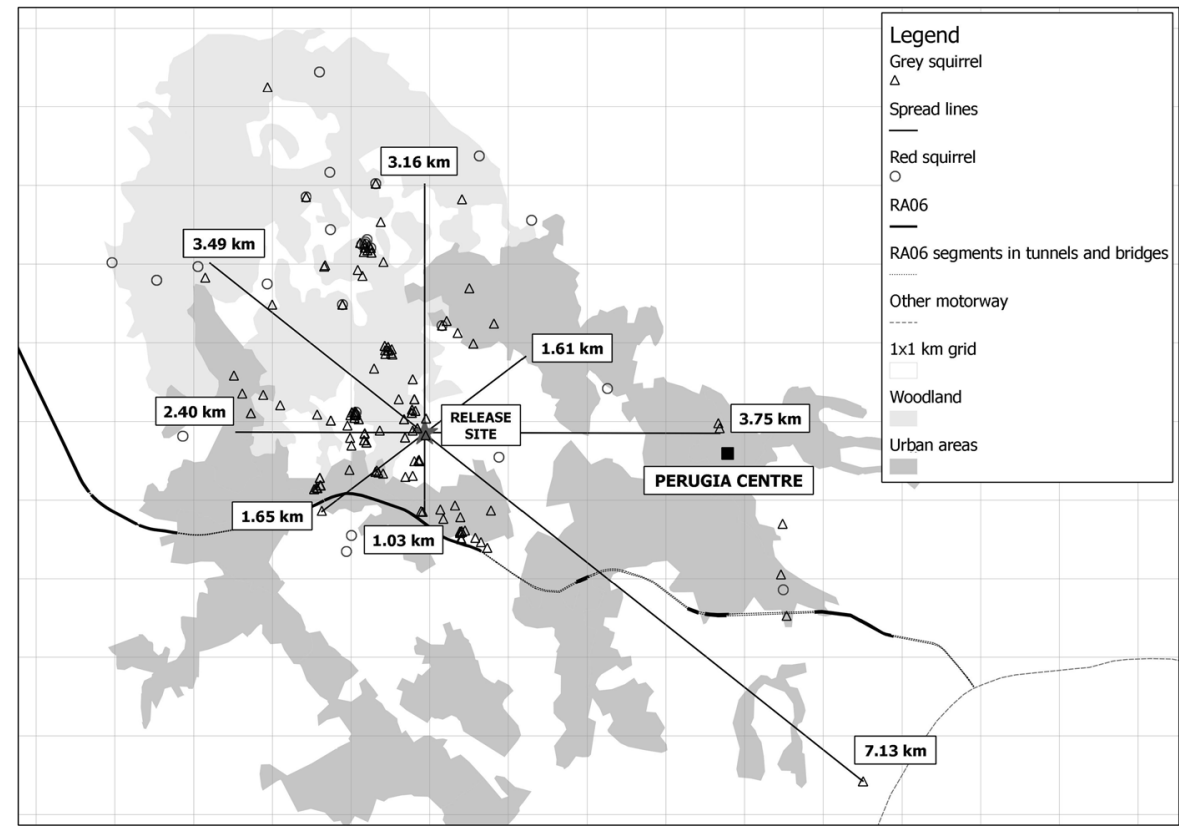

the release time. Each distance was divided by the minimum and maximum $\Delta \mathrm{t}$. The 16 individual estimates were averaged to get the point estimate of spread rate, but the individual measurements were retained as a measure of uncertainty. Andow et al. (1990) had species range data from several years, so they were able to evaluate whether spread was asymptotically linear, thereby computing the asymptotic rate; we had only 3 years data so this was infeasible and we computed only rates over the entire period from introduction to 2012 as an approximation of the asymptotic rate. We mention possible implications of this approximation in the Discussion.

\section{Results}

Genetic diversity and assignment tests

Across the 25 examined samples two loci (SCV4 and SCV13) were monomorphic, while DSF27 was monomorphic for all but one heterozygotic individual (PG22). The three markers were therefore kept to calculate genetic diversity and for the assignment tests but were excluded from the rest of the analysis. No evidence of deviation from Hardy-Weinberg equilibrium, linkage disequilibrium, allelic drop-outs, null alleles or stuttering was found for the Perugia population. The $\mathrm{F}_{\mathrm{IS}}$ value was -0.023 (95\% CI -0.163 to 0.078 ) so the inbreeding coefficient was not significant. Mean number of alleles, averaged across all loci, was $2.17 \pm 0.21$, whereas the effective number of alleles $(\mathrm{Ne})$ was $1.71 \pm 0.16$. Unbiased expected heterozygosity was $0.35 \pm 0.067$. The CI presented here and throughout the paper are $95 \%$ ranges.

STRUCTURE analysis showed no clear evidence of substructure across the different sampling locations within the Perugia region. The assignment tests attributed all the individuals from Perugia to the population in Piedmont (Signorile et al. in review) and the population on the whole was attributed to Piedmont with a $100 \%$ probability. The genetic distance $\left(\mathrm{F}_{\mathrm{ST}}\right)$ from the Piedmont population was relatively low but still significant, with a value of $0.162(P<0.001)$ (Table 2). This was expected since allelic frequencies can vary greatly as a consequence of bottlenecks and genetic drift after a translocation event.

Grey squirrel expansion in Umbria

The mean spread rate was $0.29 \mathrm{~km} /$ year, with the 16 estimates ranging from 0.09 to $0.79 \mathrm{~km} /$ year. The SD of the 16 estimates was $0.19 \mathrm{~km} /$ year, and the standard error of the mean spread rate estimate was $0.05 \mathrm{~km} /$ year. Data showed that point transects for detecting 
Table 2 Genetic distances between grey squirrels in Perugia and other populations. Stars indicate significance at a $95 \% \mathrm{CI}$

\begin{tabular}{ll}
\hline Region & Genetic distance $\left(\mathrm{F}_{\mathrm{st}}\right)$ \\
\hline Piedmont & $0.1620^{* * *}$ \\
Northern Ireland & $0.3021^{* * *}$ \\
Northumberland & $0.3134 * * *$ \\
East Anglia & $0.2516^{* * *}$ \\
West Virginia & $0.2611^{* * *}$ \\
\hline
\end{tabular}

squirrel presence were effective, because for every observation for which squirrels were detected, they were detected again on subsequent observations in the same location. Densities estimated at the two trapping locations MMA1 and FON1 were 21.7 and 32.2 individuals per hectare, respectively. During our capture sessions in the years 2011-2012 the capture ratio of reds to greys was 1:8 (10 captured reds versus 77 greys).

\section{Discussion}

Our data supported both of our initial hypotheses. They demonstrated that genetic diversity of grey squirrels around Perugia is very low following the severe bottleneck imposed when a few individuals were introduced from Piedmont, an area where genetic diversity was already low (Signorile et al. in review). It was not known prior to our work that the Perugia population had its origins in Piedmont; the double effect of low founder sizes, combined with founders from a region that had low diversity already, means diversity in Perugia is very low. Our results also showed that range expansion in Perugia has so far been very slow-comparisons to spread rates for other European populations are made below.

Genetic diversity and spread

There is limited consensus on the intrinsic physiological and ecological characteristics of good invaders, and the relationship between intrinsic characteristics of species and invasion may be complex and of limited predictive use (Kolar and Lodge 2001; Crawford and Whitney 2010). Instead, research often indicates that invasion success depends on the size of introduction events (Veltman et al. 1996; Kolar and Lodge 2001;
Cassey et al. 2004; Lockwood et al. 2005; Sol et al. 2007; Dlugosch and Parker 2008; LeRoux and Wieczorek 2009; Hardesty et al. 2012). Genetic bottlenecks at the time of introduction can cause low genetic diversity, inbreeding depression and reduced ability to adapt to the new environment, limiting the probability of successful invasion (Frankham et al. 2002). When effective population size is low, stochastic loss of genetic variation is more likely and drift can overcome selection on evolutionary pathways. This can have a long term impact on fitness and population dynamics (Lammi et al. 1999; Reed and Frankham 2003; Reed et al. 2007; Roman and Darling 2007). Conversely, many introduced individuals or multiple introductions can lead to much genetic variation, which limits inbreeding depression, promotes adaptation, and facilitates invasion. These ideas and evidence supporting them are reviewed by Sakai et al. (2001), Lee (2002), and Dlugosch and Parker (2008). The invasiveness demonstrated by grey squirrels around Perugia and elsewhere in Italy therefore may be unexpected if expectations are based on the work cited above. The success of the invasion in spite of the genetic disadvantage of the population demonstrates the overall ability of the species as an invader in Europe. Further supporting this viewpoint, by compiling records on squirrel introductions worldwide, Bertolino (2009) estimated that Sciurus populations can be established from one introduced pair with $50 \%$ success rate.

Although the population in Perugia has established and is spreading, the spread is slow in comparison with other populations in Europe. Low genetic diversity is the most probable explanation for the slownessalthough squirrels can invade even when genetically poor, the rate of invasion may be decreased. Average spread rate in Piedmont was estimated to be about $0.6 \mathrm{~km} /$ year. For Northumberland, England it was $8.25 \mathrm{~km} /$ year. For East Anglia, England, it was $5.7 \mathrm{~km} /$ year, and for Northern Ireland it was $1.92 \mathrm{~km} /$ year (Signorile et al. in review). Earlier studies (Williamson and Brown 1986; Tangney and Montgomery 1995; O’Teangana et al. 2000) estimated $7.7 \mathrm{~km} /$ year in East Anglia and $1.94 \mathrm{~km} /$ year in Ireland, similar values. These are all markedly higher than our spread rate estimate for Perugia, $0.29 \mathrm{~km} /$ year. Bertolino and Genovesi (2003) also show results that indicate a higher expansion rate in Piedmont than in Perugia. The spread rates listed here are consistent with the hypothetical explanation that genetic 
diversity is negatively correlated with population spread rate (Signorile et al. in review). Although spread rate in Perugia is slow, ecological factors appear to be entirely in favor of rapid spread, in the sense that the largely unfragmented forests surrounding Perugia are dominated by large-seeded deciduous trees, and are an ideal habitat for fast population growth for an arboreal species native to the forests of the Eastern USA were oaks, walnuts, hickory and beeches are abundant (Koprowski 1994). Densities measured at MMA1 and FON1 were high-most densities previously measured in other European woodlands have been approximately in the range 1-5 individuals per hectare (Lurz et al. 2001).

There are at least two alternative hypothetical explanations for the slow spread in Perugia that can be compared in future work to the genetic explanation we suggest here. First, "lag phases" of slow expansion are often observed in the initial stages of an invasion (Crooks 2005). The Perugia expansion may accelerate after some years of initial slow expansion. Second, it was suggested by a referee of this study that fragmentation may speed population range expansion in some circumstances (With 2002). Hence slow expansion in Perugia may have been caused by the unfragmented nature of the Perugia forest instead of happening in spite of it, according to this hypothesis. One possible mechanism for such an effect would be if fragmentation forces individual squirrels to undergo larger dispersal events in order to bridge gaps between fragments. But the modelling and empirical results reviewed by With (2002) seem to suggest that greater habitat coverage is usually or always associated with faster range expansion. Another possible mechanism is that some degree of fragmentation is actually beneficial to grey squirrel ecology. Koprowski (2005) found a negative relationship between grey squirrel density and fragment size, and Fisher and Merriam (2000) found higher grey squirrel densities in fragmented landscapes than in continuous forest. However, as mentioned above, densities of grey squirrels in the Perugia region were quite high, casting doubt, in our view, on the hypothesis that lack of fragmentation is what has slowed expansion in the Perugia area. Nevertheless, landscape effects on spread rate involve a complex interaction of species demography, dispersal behaviour, ability to detect distant fragments, and precise landscape layout; further evaluation of landscape effects on spread rate and comparison to genetic effects will be an interesting topic for future research.

We detected no spatial genetic structure in the Perugia population using STRUCTURE; this contrasts with our earlier work in which we found structure at small spatial scales in populations in Piedmont and elsewhere (Signorile et al. in review). Lack of structure is probably due to the recency of the introduction or dispersal within the area or both. Structure would be expected to emerge as the population range expands, mirroring what was found, for instance, in Piedmont.

The method used here for calculating spread rate was quite similar to widely used methods described in Andow et al. (1990), but with a few differences because of the nature of our data. Andow et al. (1990) had several population range maps for their species of study, gathered at intervals over a long period of time. So they were able to compute spread rates over intervals and investigate whether the theoretical expectation held that spread was asymptotically linear. But Andow et al. (1990) selected species for study for which data were especially abundant, whereas we were interested for this paper in an important new population of grey squirrel, for which data were good but more limited than those of Andow et al. (1990). We calculated one spread rate per direction for each possible start date, using 2012 data, rather than extrapolating successive estimates over time to an asymptotic rate. This is an approximation of the asymptotic rate of Andow et al. (1990). We tried calculating spread rates for the successive years 2010 2012, and results were similar to those presented here, but because only 3 years of data were available this was not an improvement, and the simpler method was presented. Our estimated spread rate may be an underestimate if asymptotic rate has not been acheived (e.g., if the Perugia population is in a lag phase of expansion-see above), but because spread rate differences with other European populations are so large, spread rate will have to increase dramatically to approach levels seen elsewhere. Andow et al. (1990) also make a comparison between spread rates calculated from range map data and rates estimated using the formula $\sqrt{4 \alpha D}$, where $\alpha$ is an intrinsic growth rate and $D$ is the diffusion coefficient for the species. But this formula is not suitable for our study because estimates of $\alpha$ and $D$ are not available for the Perugia population 
or for the other populations to which comparisons of spread rate were made.

\section{Ecological issues}

Umbria is covered by extensive and largely unfragmented secondary forests for over $60 \%$ of its territory (Regione Umbria et al. 2009). Therefore, grey squirrels have the potential to spread dramatically. From Umbria, squirrels may well move freely northwards and southwards along the Apennine mountains to occupy the whole Italian peninsula. This is the first time that grey squirrels have occupied an extensive, continuous, forested area in continental Europe. Although grey squirrel spread is currently slow, ecological consequences could be serious in the long term, or in the shorter term if spread rate increases.

Although red and grey squirrels are sympatric at present, it is unlikely the peninsular woodlands will be able to indefinitely support both species. Competitive exclusion mechanisms (Wauters and Gurnell 1999) could already be acting on the red squirrel population; grey squirrels were much more commonly captured in the area than were red squirrels. Exclusion effects could become more evident in the next few years. If this proves to be the case, the presence of the grey squirrel will lead to local and regional extinctions of red squirrels.

Invasion of the grey squirrel may have consequences for the forest ecosystems of central and southern Italy more broadly than disappearance of the red squirrel. Squirrels have an important ecological role as seed dispersers because of their scatterhoarding behaviour, and mutualistic relationships have evolved between tree species and squirrels (Wall 2001). Further studies would be needed to assess the capacity of the ecosystem to adapt to the replacement of the native red squirrel species with the grey squirrel, a species usually living at higher densities and with potentially subtly different seed hoarding and consumption behaviours. Red and grey squirrels overlap in their food preferences (Wauters et al. 2002), so replacement of red with grey squirrels may or may not lead to any substantive change in forest composition in the longer term. Although grey squirrels in the UK are known to debark and kill forest trees (Rowe and Gill 1985; Kenward and Parish 1986; Dagnall et al. 1998), this behaviour has not been observed in Italy (Signorile and Evans 2006). We have focussed here on the importance of the grey squirrel expansion in Perugia as derived from the threat the grey squirrel represents for $S$. v. italicus and $S$. v. meridionalis because that threat is very clear based on past observed interactions between grey and red squirrels elsewhere in Europe, whereas wider effects of the species replacement on southern Italian ecosystems may also be important but require further study.

The single squirrel seen at distance $7.13 \mathrm{~km}$ from the release site (Fig. 2) may have come from a humanmediated dispersal event from the main population centre West of the city, or it may have been part of a natural spread through a green belt north of the city. Future work should include sampling north of the city in the green belt. In addition, the distribution of grey squirrel sightings (Fig. 2) seems to suggest that the motorway RA06 has been a barrier to southward grey squirrel expansion. But because a few squirrels have recently been seen south of the road, the barrier appears to recently have been traversed. The section of the motorway closest to the release point is surface highway, but nearby sections are bridges or tunnels, which provide reduced or no barrier. Faster expansion south may be expected in the next several years now that the motorway barrier has been passed.

\section{Conservation and research priorities}

The grey squirrel population around Perugia should be eradicated. We have demonstrated that the population is expanding, albeit slowly, and it seems likely that new releases that increase genetic diversity will also increase spread rate: introgression of new genotypes, even of just a few individuals, could generate novel phenotypes, reduce the genetic load and have an effect on the evolutionary responses of invading populations (Lee 2011). The Perugia grey squirrel population is probably the only grey squirrel population that overlaps with the range of $S$. v. italicus, and is by far the closest population to the range of $S$. v. meridionalis. The expansion of the Perugia grey squirrel nucleus is probably the principle conservation threat to these subspecies (see below). New releases and increased spread rate are not unlikely given current enforcement of laws on invasive species. Grey squirrels were included in 2012 in Annex B of European Community Regulation 338/97, and this should prevent further imports from the species' natural range. However, the grey squirrels released in Perugia and purchased from 
the pet trade were taken from Piedmont, another Italian location. Grey squirrel live-captures for any purpose other than scientific studies are strictly regulated in Italy by law 157/92. Squirrels in the pet trade circuit can therefore come from other Italian locations only through an initial illegal poaching act, and it cannot be ruled out that this could happen again, especially given lax enforcement. Hence eradication is probably the only way to eliminate the threat posed to the peninsular Italian red squirrel subspecies. Eradication is very likely still possible and practical. For instance, eradication of the Piedmont population of grey squirrels was considered practical in 1997, when that population covered $380 \mathrm{~km}^{2}$ (Bertolino and Genovesi 2003), far more than the $<50 \mathrm{~km}^{2}$ covered in the Perugia region. Eradication seems likely to be feasible for at least the next 10 years or longer, since the Piedmont population was established in 1948, and it was still considered practical to eradicate in 1997. But this is not guaranteed, especially if additional genetic diversity is imported to the Perugia population. Rapid action is considered crucial to successful eradication (Genovesi et al. 2010), as the task gets harder with population expansion. In addition, further translocations within the area or into the range of $S$. $v$. meridionalis are more likely with a nucleus at Perugia.

Past attempts to eradicate grey squirrel populations in Italy have been thwarted by animal rights activists (Bertolino and Genovesi 2003). If eradication is not possible because of this human dimension, the recent EU Regulation 757/2012 and the Legislative decree 24/12/2012 signed by the Italian government are steps in the right direction-these laws are aimed at forbidding the grey squirrel pet trade, releases in the wild, and import. Citizens should be educated about the ecological risks of buying, moving or releasing exotic species, and enforcement of these regulations should be vigilant.

Broader conservation of the Italian peninsular red squirrel subspecies, beyond the mitigation of the threat posed by grey squirrels, should focus on research because, to our knowledge, little has been published on the subspecies $S$. v. italicus and $S$. v. meridionalis regarding many aspects of their range, density, demography, genetics, behaviour, ecology or the threats they face, if any, other than the grey squirrel. Habitat loss and destruction have been found in extensive research to strongly affect $S$. vulgaris generally (Wauters et al. 1994; Verbeylen et al. 2003, 2009), with sensitivity to habitat fragmentation especially emphasized, for instance, by Koprowski (2005). Mortelliti et al. (2011) argued instead that what matters is habitat loss, not fragmentation per se. However, the vast majority of studies of red squirrel ecology use study locations outside the likely ranges of $S$. v. italicus and $S . v$. meridionalis (but see Mortelliti et al. (2011)), and we are aware of no studies that compare and contrast the ecology and demography of these subspecies with other red squirrel populations. Perhaps more importantly, there has been no research on whether the particular sensitivities of $S$. vulgaris to habitat layout and amount, combined with the past and projected changes of habitat in peninsular Italy, actually represent a real threat to $S$. $v$. italicus and S. v. meridionalis in the way that the grey squirrel represents a real and present danger to the subspecies.

Acknowledgments The authors thank P. Lurz, S. Bertolino, J. Wang, C. Carbone, C. Loudin, P. Reuman, A. Reuman, and anonymous referees for assistance, advice, and suggestions which informed this work. Squirrel population range data and samples were collected by researchers in the Department of Cell and Environmental Biology, University of Perugia, with financial support from the Hunting and Fishing Service of the Region of Umbria. A squirrel Management Plan written by the Province of Perugia and approved by the Italian Institute of Protection and Environmental Research (ISPRA) and Ministry of Environment (MATTM) permitted the legal capture, removal and handling of squirrels. Genetic research and data analysis were funded through a UK Natural Environment Research Council (NERC) CASE PhD studentship supporting ALS, grant NE/G011842/1. DCR was partly supported by NERC Grants NE/H020705/1, NE/I010963/1, and NE/I011889/1.

Open Access This article is distributed under the terms of the Creative Commons Attribution License which permits any use, distribution, and reproduction in any medium, provided the original author(s) and the source are credited.

\section{References}

Amori G, Contoli L, Nappi A (2008) Mammalia II. Erinaceomorpha, Soricomorpha, Lagomorpha, Rodentia. Fauna d'Italia, vol. XLIV. 736

Andow DA, Kareiva PM, Levin SA, Okubo A (1990) Spread of invading organisms. Landsc Ecol 4:177-188. doi:10.1007/ BF00132860

Belkhir K, Borsa P, Chikhi L, et al. (2004) GENETIX 4.05, logiciel sous Windows TM pour la génétique des populations. Laboratoire Génome (1996-2004) Populations, Interactions, CNRS UMR 5171, Université de Montpellier II, Montpellier (France) 
Bertolino S (2009) Animal trade and non-indigenous species introduction: the world-wide spread of squirrels. Divers Distrib 15:701-708. doi:10.1111/j.1472-4642.2009.00574.X

Bertolino S, Genovesi P (2003) Spread and attempted eradication of the grey squrirrel (Sciurus carolinensis) in Italy, and consequences for the red squirrel (Sciurus vulgaris) in Eurasia. Biol Conserv 109:351-358

Bertolino S, Genovesi P (2005) The application of the European strategy on invasive alien species: an example with introduced squirrels. Hystrix 16:59-69. doi:10.4404/hystrix-16. 1-4343

Cassey P, Blackburn TM, Sol D et al (2004) Global patterns of introduction effort and establishment success in birds. Proc Biol Sci 271(Suppl):S405-S408. doi:10.1098/rsbl.2004. 0199

Crawford KM, Whitney KD (2010) Population genetic diversity influences colonization success. Mol Ecol 19:1253-1263. doi:10.1111/j.1365-294X.2010.04550.X

Crooks JA (2005) Lag times and exotic species: the ecology and management of biological invasions in slow-motion. Ecoscience 12:316-329. doi:10.2980/11195-6860-12-3316.1

Dagnall J, Gurnell J, Pepper H (1998) Bark-stripping by gray squirrels in state forests of the United Kingdom: a review. In: Steele MA, Merritt JF, Zegers DA (eds) Molecular biology and evolution.Tree squirrels. Virginia Museum of Natural History, Martinsville, pp 249-262

Dlugosch KM, Parker IM (2008) Founding events in species invasions: genetic variation, adaptive evolution, and the role of multiple introductions. Mol Ecol 17:431-449. doi:10.1111/j.1365-294X.2007.03538.x

Fike JA, Rhodes OE (2009) Characterization of twenty-six polymorphic microsatellite markers for the fox squirrel (Sciurus niger) and their utility in gray squirrels (Sciurus carolinensis) and red squirrels (Tamiasciurus hudsonicus). Conserv Genet 10:1545-1548. doi:10.1007/s10592-0089789-5

Fisher JT, Merriam G (2000) Resource patch array use by two squirrel species in an agricultural landscape. Landsc Ecol 15:333-338

Frankham R, Ballou JD, Briscoe DA (2002) Introduction to conservation genetics. Cambridge University Press, Cambridge, p 617

Genovesi P, Scalera R, Brunel S et al (2010) Towards an early warning and information system for invasive alien species (IAS) threatening biodiversity in Europe. European Environment Agency, Copenhagen, p 47

Goudet J (1995) FSTAT (Version 1.2): a computer program to calculate F-statistics. J Hered 86:485-486

Grill A, Amori G, Aloise G et al (2009) Molecular phylogeography of European Sciurus vulgaris: refuge within refugia? Mol Ecol 18:2687-2699. doi:10.1111/j.1365-294X.2009. 04215.x

Gurnell J, Wauters LA, Lurz PWW, Tosi G (2004) Alien species and interspecific competition: effects of introduced eastern grey squirrels on red squirrel population dynamics. J Anim Ecol 73:26-35. doi:10.1111/j.1365-2656.2004.00791.x

Hale ML, Bevan R, Wolff K (2001) New polymorphic microsatellite markers for the red squirrel (Sciurus vulgaris) and their applicability to the grey squirrel (S. carolinensis). Mol
Ecol Notes 1:47-49. doi:10.1046/j.1471-8278.2000. 00020.x

Hardesty BD, Le Roux JJ, Rocha OJ et al (2012) Getting here from there: testing the genetic paradigm underpinning introduction histories and invasion success. Divers Distrib 18:147-157. doi:10.1111/j.1472-4642.2011.00832.x

Kalinowski ST, Manlove KR, Taper ML (2008) ONCOR: a computer program for genetic stock identification, v.2. http://www.montana.edu/kalinowski/ONCOR/ONCOR_ Manual_210ct2007.pdf

Kenward RE, Parish T (1986) Bark-stripping by grey squirrels (Sciurus carolinensis). J Zool 210:473-481

Kolar CS, Lodge DM (2001) Progress in invasion biology: predicting invaders. Trends Ecol Evol 16:199-204

Koprowski JL (1994) Sciurus carolinensis. The American Society of Mammalogists, New york

Koprowski JL (2005) The response of tree squirrels to fragmentation: a review and synthesis. Anim Conserv 8: 369-376

Kot M, Lewis MA, van den Driessche P (1996) Dispersal data and the spread of invading organisms. Ecology 77: 2027-2042

Lammi A, Siikamaki P, Mustajarvi K (1999) Genetic diversity, population size, and fitness in central and peripheral populations of a rare plant Lychnis viscaria. Conserv Biol 13:1069-1078. doi:10.1046/j.1523-1739.1999.98278.x

Lance SL, Maldonado JE, Bocetti CI et al (2003) Genetic variation in natural and translocated populations of the endangered delmarva fox squirrel (Sciurus niger cinereus). Conserv Genet 4:707-718. doi:10.1023/B:COGE.0000006112. $18846.9 f$

Lee CE (2002) Evolutionary genetics of invasive species. Trends Ecol Evol 17:386-391. doi:10.1016/S0169-5347 (02)02554-5

Lee CE (2011) Evolution of invasive populations. In: Simberloff D, Rejmánek M (eds) Encyclopedia of biological invasions. University of California Press, California, p 765

LeRoux J, Wieczorek AM (2009) Molecular systematics and population genetics of biological invasions: towards a better understanding of invasive species management. Ann Appl Biol 154:1-17. doi:10.1111/j.1744-7348.2008.00280.x

Lloyd HG (1983) Past and present distribution of red and grey squirrels. Mamm Rev 13:69-80

Lockwood J, Cassey P, Blackburn TM (2005) The role of propagule pressure in explaining species invasions. Trends Ecol Evol 20:223-228. doi:10.1016/j.tree.2005. 02.004

Lowe S, Browne M, Boudjelas S, De Poorter M. (2000) 100 of the world's worst invasive alien species a selection from the global invasive species database, 2 Nov 12

Lurz PWW, Rushton SP, Wauters LA et al (2001) Predicting grey squirrel expansion in North Italy: a spatially explicit modelling approach. Landsc Ecol 16:407-420

Lurz PWW, Gurnell J, Magris L (2005) Sciurus vulgaris. Mamm Species 769:1-10. doi:10.1644/1545-1410(2005) 769[0001:SV]2.0.CO;2

Martinoli A, Bertolino S, Preatoni D et al (2010) Headcount 2010: the multiplication of the grey squirrel populations introduced to Italy. Hystrix Ital J Mammal 21:127-136. doi:10.4404/Hystrix-21.2-4463 
Middleton AD (1930) The ecology of the American grey squirrel (Sciurus carolinensis Gmelin) in the British Isles. In: Proceeding of Zoological Society of London, 810-843

Middleton AD (1931) The grey squirrel. Sidgwick \& Jackson LTD, London

Mortelliti A, Amori G, Capizzi D et al (2011) Independent effects of habitat loss, habitat fragmentation and structural connectivity on the distribution of two arboreal rodents. J Appl Ecol 48:153-162. doi:10.1111/j.1365-2664.2010. 01918.x

O’Teangana D, Reilly S, Montgomery WI, Rochford J (2000) Distribution and status of the red squirrel (Sciurus vulgaris) and grey squirrel (Sciurus carolinensis) in Ireland. Mamm Rev 30:45-56. doi:10.1046/j.1365-2907.2000.00054.x

Paoloni D, Vercillo F., Ragni B. (2010) Lo scoiattolo grigio Sciurus carolinensis gmelin, 1788 in Umbria: un rischio incombente. In: Bertolino S., Capizzi D., Mortelliti A., Amori G (ed) Convegno Ital. sui Piccoli Mammiferi. p 44

Paoloni D, Minciarelli L, Croce M et al. (2012) A contribute to biodiversity: Eastern grey squirrel management approach for the conservation of red squirrel in Umbria (Central Italy). In: Prigioni C, Balestrieri A, Preatoni DG, Masseroni E (eds) VIII Congr. It. Teriologia, Hystrix, It. J. Mamm. Supp. 2012. pp 1-200

Pritchard JK, Stephens M, Donnelly P (2000) Inference of population structure using multilocus Genotype data. Genetics 155:945-959

Rannala B, Mountain J (1997) Detecting immigration by using multilocus genotypes. Proc Natl Acad Sci USA 94: 9197-9201

Raymond M, Rousset F (1995) GENEPOP (Version 1.2): population genetics software for exact tests and ecumenicism. J Hered 86:248-249

Reed DH, Frankham R (2003) Correlation between fitness and genetic diversity. Conserv Biol 17:230-237. doi:10.1046/j. 1523-1739.2003.01236.x

Reed DH, Nicholas AC, Stratton GE (2007) Genetic quality of individuals impacts population dynamics. Anim Conserv 10:275-283. doi:10.1111/j.1469-1795.2007.00120.x

Regione Umbria, Università degli Studi di Perugia, Università degli Studi dell' Aquila, Università degli Studi di Camerino, University of Cambridge, University of Reading WRIA (2009) RERU, Rete Ecologica Regionale dell'Umbria, Ecological Network of Umbria. 241

Reynolds JC (1985) Details of the geographic replacement of the red squirrel (Sciurus vulgaris) by the grey squirrel (Sciurus carolinensis) in Eastern England. J Anim Ecol 54:149. doi: $10.2307 / 4627$

Roman J, Darling JA (2007) Paradox lost: genetic diversity and the success of aquatic invasions. Trends Ecol Evol 22: 454-464

Rowe JJ, Gill RMA (1985) The susceptibility of tree species to bark-stripping damage by grey squirrels (Sciurus carolinensis) in England and Wales. Q J For 79:183-190

Rushton S, Garson PJ (1995) Predicting changes in squirrel distributions in Scotland from 1995 to 2025. Scottish Nat Herit Rev 76:42

Rushton SP, Lurz PWW, Fuller R, Garson PJ (1997) Modelling the distribution of the red and grey squirrel at the landscape scale: a combined GIS and population dynamics approach. J Appl Ecol 34:1137-1154
Rushton SP, Gurnell J, Lurz PWW, Fuller RM (2002) Modelling impacts and costs of gray squirrel control regimes on the viability of red squirrel populations. J Wildl Manage 66:683-697

Sainsbury AW, Deaville R, Lawson B et al (2008) Poxviral disease in red squirrels Sciurus vulgaris in the UK: spatial and temporal trends of an emerging threat. EcoHealth 5:305-316. doi:10.1007/s10393-008-0191-z

Sakai AK, Allendorf FW, Holt JS et al (2001) The population biology of invasive species. Annu Rev Ecol Syst 32:305-332

Sidorowicz J (1971) Problems of subspecific taxonomy of squirrel (Sciurus vulgaris L.) in Palaearctic. Zool Anz 187:123-142

Signorile AL, Evans J (2006) Damage caused by the American grey squirrel (Sciurus carolinensis) to agricultural crops, poplar plantations and semi-natural woodland in Piedmont, Italy. Forestry 80:89-98. doi:10.1093/forestry/cpl044

Signorile AL, Wang J, Lurz PWW et al. (In Review) Do founder size, genetic diversity and structure influence rates of expansion of North American grey squirrels in Europe? Divers. Distrib

Sol D, Vilà M, Kühn I (2007) The comparative analysis of historical alien introductions. Biol Invasions 10:1119-1129. doi:10.1007/s10530-007-9189-7

Tangney DE, Montgomery WI (1995) The distribution and habitat associations of red and grey squirrels in Northern Ireland. 118

Thulin C-G, Simberloff D, Barun A et al (2006) Genetic divergence in the small Indian mongoose (Herpestes auropunctatus), a widely distributed invasive species. Mol Ecol 15:3947-3956. doi:10.1111/j.1365-294X.2006.03084.x

Tompkins DM, White AR, Boots M (2003) Ecological replacement of native red squirrels by invasive greys driven by disease. Ecol Lett 6:189-196. doi:10.1046/j.14610248.2003.00417.x

Toschi A (1965) Marnmalia. Lagomorpha-Rodentia-CarnivoraArtiodactyla-Cetacea. Fauna d'Italia, Vol. 7. p 647

Van Oosterhout C, Hutchinson B, Wills D, Shipley P (2004) MICRO-CHECKER: software for identifying and correcting genotyping errors in microsatellite data. Mol Ecol Notes 4:535-538

Veltman CJ, Nee S, Crawley MJ (1996) Correlates of introduction success in exotic New Zealand birds. Am Nat 147:542-557

Venturini M, Franzetti B, Genovesi P et al (2005) Distribuzione e consistenza della popolazione di Scoiattolo grigio sciurus carolinensis gmelin, 1788 nel levante genovese. Hystrix Ital J Mammal 16:53-58

Verbeylen G, De Bruyn L, Matthysen E (2003) Pazch occupancy, population density and dynamics in a fragmented red squirrel Sciurus vulgaris population. Ecography (Cop) 26:118-128

Verbeylen G, Wauters LA, De Bruyn L, Matthysen E (2009) Woodland fragmentation affects space use of Eurasian red squirrels. Acta Oecologica 35:94-103

Walker NF, Hulme PE, Hoelzel AR (2003) Population genetics of an invasive species, heracleum mantegazzianum: implications for the role of life history, demographics and independent introductions. Mol Ecol 12:1747-1756. doi:10.1046/j.1365-294X.2003.01866.x

Wall SB (2001) The evolutionary ecology of nut dispersal. Bot Rev 67:74-117. doi:10.1007/BF02857850 
Wauters LA, Gurnell J (1999) The mechanism of replacement of red squirrels by grey squirrels: a test of the interference competition hypothesis. Ethology 105:1053-1071

Wauters LA, Hutchinson Y, Parkin DT, Dhondt AA (1994) The effects of habitat fragmentation on demography and on the loss of genetic variation in the red squirrel. Proc R Soc London 255:107-111

Wauters LA, Somers L, Dhondt AA (1997) Settlement behaviour and population dynamics of reintroduced red squirrels Sciurus vulgaris in a park in Antwerp, Belgium. Biol Conserv 82:101-107

Wauters LA, Tosi G, Gurnell J (2002) Interspecific competition in tree squirrels: do introduced grey squirrels (Sciurus carolinensis) deplete tree seeds hoarded by red squirrels ( $\mathrm{S}$. vulgaris)? Behav Ecol Sociobiol 51:360-367
Weir BS, Cockerham CC (1984) Estimating F-statistics for the analysis of population structure. Evolution ( $\mathrm{Ny}$ ) 38: $1358-1370$

Williamson MH, Brown K (1986) The analysis and modeling of British invasions. Philos Trans R Soc Biol Sci 314: 505-522

With KA (2002) The landscape ecology of invasive spread. Conserv Biol 16:1192-1203. doi:10.1046/j.1523-1739. 2002.01064.x

Zeisset I, Beebee TJC (2003) Population genetics of a successful invader: the marsh frog rana ridibunda in Britain. Mol Ecol 12:639-646

Zippin C (1958) The removal method of population estimation. J Wildl Manage 22:82-90 